\title{
Editorial
}

\section{The Lessons of September 11}

The attacks on the World Trade Center (WTC) of September 11, 2001 caused a massive environmental disaster and resulted in the deaths of 2,823 persons. They also generated a long-lasting burden of illness in the more than 50,000 rescue workers who responded to the attacks and in the 400,000 residents and workers in nearby areas of New York City. Many of these illnesses continue to this day.

We have learned much from the experience of September 11 about the acute and delayed health effects of civilian catastrophes. We have also learned critical lessons about the importance of having trained responders - medical as well as non-medical - in place in advance of disasters, and about the need to maintain medical surveillance of exposed populations long after a disaster has occurred.

\section{The Medical Response to September 11}

Our medical response to the attacks of September 11 began immediately following the attacks. Physician specialists in occupational and environmental medicine (OEM) and industrial hygienists at the Mount Sinai School of Medicine came together to formulate a medical response plan based on our extensive prior experience with injured workers and military veterans ${ }^{1}$.

Within a few days we began to treat sick and injured workers. We observed respiratory health effects, especially cough and severe rhinosinusitis, as well as psychological effects, especially post-traumatic stress disorder (PTSD). On the basis of these early observations, we realized that a systematic program for medical monitoring would be required and that it must include physical as well as mental health examinations ${ }^{2}$. This initial response would not have been possible without the presence of highly trained physicians and industrial hygienists.

Our physicians, in close partnership with the leaders of New York City's major labor unions, advocated to the US Congress and to the National Institute for Occupational Safety \& Health (NIOSH) about the need for a comprehensive medical monitoring programs for rescue workers and civilian survivors. This advocacy resulted in the establishment of medical monitoring programs to care for rescue workers and civilian survivors. The medical program at the fire department of the City of New York (FDNY) has provided especially useful information about the health consequences of September
11, because for many years before the attacks FDNY's medical program had mandated an annual physical examination for all firefighters and paramedics that included spirometry. These baseline data obtained before the disaster have yielded a series of valuable insights ${ }^{3)}$.

\section{Initial Symptoms}

September 11 rescue workers sustained intense, shortterm exposures to airborne toxic materials that were generated during the collapse of the towers. Two-thirds of the mass of this airborne material was pulverized cement, and as a result the dust was highly alkaline $(\mathrm{pH} 10-11)^{4)}$. Cough and bronchial hyperreactivity were the predominant initial physical symptoms. This cough was named the "World Trade Center Cough" and was defined as severe cough in rescue workers who had served at the WTC site that persisted for at least four weeks. World Trade Center cough occurred in 8 percent of firefighters with a high level of exposure, in 3 percent with a moderate level of exposure, and in 1 percent with a low level of exposure ${ }^{5)}$.

\section{Persistence of Symptoms}

Banauch et al. (2003) studied the persistence of the initial findings and found highly exposed workers were 6.8 times more likely than moderately exposed workers and unexposed workers to be hyperreactive ${ }^{6}$. A parallel study of more than 9,000 September 11 responders other than firefighters found that $69 \%$ had developed new onset or worsened respiratory symptoms while working at the WTC site. These symptoms persisted up to $2.5 \mathrm{yr}$ after the attacks ${ }^{2}$. A nine-year follow-up of 27,449 rescue workers demonstrated that the cumulative incidence of asthma was $27.6 \%$, of sinusitis $42.3 \%$, and of gastroesophageal reflux disease $39.3 \%$. Incidence of most of these disorders was highest in workers with greatest exposure. Extensive comorbidity was reported within and between physical and mental health disorders ${ }^{7)}$. A nine-year follow-up of civilian survivors of September 11 found a cumulative incidence of $20 \%$ for post-September 11 gastroesophageal reflux symptoms (GERS) and $13 \%$ for persistent GERS ${ }^{8)}$. Among civilian survivors with no stated asthma history, 10.2\% reported new diagnoses of asthma after September 119). Reibman et al. (2005) found new-onset respiratory symptoms in $55.8 \%$ of residents in the exposed area 
after September 11, compared with $20.1 \%$ in a distant $\operatorname{area}^{10)}$.

\begin{abstract}
Abnormalities in Pulmonary Function
Banauch et al. (2006) conducted a longitudinal study of pulmonary function in FDNY firefighters ${ }^{11)}$. The main finding was that rescue workers experienced an average 372-ml reduction in adjusted average FEV1 in the year following September 11, 2001, a decline equivalent to $12 \mathrm{yr}$ of normal aging. These reductions persisted over at least $6 \mathrm{yr}^{3}$ ). Most of this reduction in lung function was due to airways obstruction ${ }^{12)}$. A nine-year follow-up of 27,449 rescue workers found that cumulative incidence for spirometric abnormalities was $41.8 \%$; three-quarters of these abnormalities were low forced vital capacity ${ }^{7}$.
\end{abstract}

\section{Sarcoidosis}

Izbicki et al. (2007) demonstrated a dramatic increase in the incidence rate of "sarcoid-like" granulomatous disease in firefighters in the first years after September $11^{13)}$. Incidence increased to $22 / 100,000$ compared to $15 / 100,000$ prior to the disaster. An increase in sarcoidlike illness has been demonstrated also in other WTC responders, especially in workers who served on the debris pile ${ }^{14)}$.

\section{Mental Health Consequences}

Stellman et al. (2008) found that $11.1 \%$ of rescue workers met criteria for probable post-traumatic stress disorder (PTSD), 8.8\% met criteria for probable depression, $5.0 \%$ met criteria for probable panic disorder, and $62 \%$ met criteria for substantial stress reaction ${ }^{15}$. PTSD was significantly associated with loss of family members and friends, disruption of family, work, and social life, and higher rates of behavioral symptoms in children of workers. PTSD prevalence was comparable to that seen in returning Afghanistan war veterans and was much higher than in the U.S. general population. Berninger et al. (2010) found that 15.5\% of 5,656 FDNY firefighters reported probable PTSD after September 11, 8.6\% at baseline and $11.1 \%$ at follow-up ${ }^{16)}$. Among civilian survivors of September 11, Brackbill et al. (2009) reported that $23.8 \%$ reported PTS symptoms ${ }^{9}$.

\section{The Importance of Worker Training in Preventing PTSD}

Worker preparation and training substantially reduced risk of PTSD. Perrin et al. (2007) found that the overall prevalence of PTSD among rescue/recovery workers was $12.4 \%$, ranging from $6.2 \%$ for trained police to $21.2 \%$ for untrained and unaffiliated volunteers ${ }^{17}$.
Debchoudhury et al. (2011) confirmed these findings and found that unaffiliated volunteers had greater risk of early mental health diagnosis, chronic PTSD, and lateonset $\mathrm{PTSD}^{18)}$.

\section{Co-Morbidity of Physical and Mental Health Problems}

Li et al. (2011) found the incidence of postSeptember 11 GERS to be higher in individuals with asthma or PTSD than in those without either condition, and highest in those with both comorbid conditions ${ }^{8}$. Wisnivesky et al. (2011) found extensive comorbidity between and among physical and mental health syndromes $^{7}$.

\section{The Importance of Respiratory Protection}

Antao et al. (2011) found that workers who wore respirators were less likely to report adverse respiratory outcomes ${ }^{19}$ ). Use of respiratory protection was most frequent among union workers who had previously received training.

\section{Summary of Lessons Learned from September 11}

The September 11disaster has reinforced many of the basic teachings of occupational and environmental medicine (OEM). Five critical lessons are these:

1. Training in OEM supported by NIOSH for more than $20 \mathrm{yr}$ before September 11 had created a cadre of OEM physicians and industrial hygienists. These trained responders were prepared to rapidly establish and build a medical program after the disaster. Without prior training in OEM, response would have been impossible.

2. The importance of collecting baseline health information collected before a disaster was demonstrated by the great value of the preSeptember 11 data that had been obtained by the FDNY Medical Department.

3. Worker training and prior experience substantially reduced risk of PTSD and increased use of respiratory protection.

4. The critical need to anticipate mental health problems in responders to civilian disasters and to provide mental health treatment that is coordinated with medical treatment.

5. The recent findings of elevated cancer rates in FDNY firefighters ${ }^{20)}$ and of elevated heart disease mortality in civilian survivors of September 1121) underscore the need for continued, long-term monitoring of populations at risk from civilian disasters.

Disasters are inevitable, but the disease sequelae of 
disaster can be minimized by appropriate training and adequate preparation.

\section{References}

1) Levin SM, Herbert R, Moline JM, Todd AC, Stevenson L, Landsbergis P, Jiang S, Skloot G, Baron S, Enright P (2004) Physical health status of World Trade Center rescue and recovery workers and volunteers —New York City, July 2002-August 2004. MMWR 53, 807-12.

2) Herbert R, Moline J, Skloot G, Metzger K, Baron S, Luft B, Markowitz S, Udasin I, Harrison D, Stein D, Todd A, Enright P, Stellman JM, Landrigan PJ, Levin SM (2006) The World Trade Center disaster and the health of workers: five-year assessment of a unique medical screening program. Environ Health Perspect 114, 1853-8.

3) Aldrich TK, Gustave J, Hall CB, Cohen HW, Webber MP, Zeig-Owens R, Cosenza K, Christodoulou V, Glass L, Al-Othman F, Weiden MD, Kelly KJ, Prezant DJ (2010) Lung function in rescue workers at the World Trade Center after 7 years. N Engl J Med 362, 1263-72.

4) Landrigan PJ, Lioy PJ, Thurston G, Berkowitz G, Chen LC, Chillrud SN, Gavett SH, Georgopoulos PG, Geyh AS, Levin S, Perera F, Rappaport SM, Small C; NIEHS World Trade Center Working Group (2004) Health and environmental consequences of the world trade center disaster. Environ Health Perspect 112, 731-9.

5) Prezant DJ, Weiden M, Banauch GI, McGuinness G, Rom WN, Aldrich TK, Kelly KJ (2002) Cough and bronchial responsiveness in firefighters at the World Trade Center site. N Engl J Med 347, 806-15.

6) Banauch GI, Alleyne D, Sanchez R, Olender K, Cohen HW, Weiden M, Kelly KJ, Prezant DJ (2003) Persistent hyperreactivity and reactive airway dysfunction in firefighters at the World Trade Center. Am J Respir Crit Care Med 168, 54-62.

7) Wisnivesky JP, Teitelbaum SL, Todd AC, Boffetta P, Crane M, Crowley L, de la Hoz RE, Dellenbaugh C, Harrison D, Herbert R, Kim H, Jeon Y, Kaplan J, Katz C, Levin S, Luft B, Markowitz S, Moline JM, Ozbay F, Pietrzak RH, Shapiro M, Sharma V, Skloot G, Southwick S, Stevenson LA, Udasin I, Wallenstein S, Landrigan PJ (2011) Persistence of multiple illnesses in World Trade Center rescue and recovery workers: a cohort study. Lancet 378, 888-97.

8) Li J, Brackbill RM, Stellman SD, Farfel MR, MillerArchie SA, Friedman S, Walker DJ, Thorpe LE, Cone J (2011) Gastroesophageal Reflux Symptoms and Comorbid Asthma and Posttraumatic Stress Disorder Following the 9/11 Terrorist Attacks on World Trade Center in New York City. Am J Gastroenterol (in press)

9) Brackbill RM, Hadler JL, DiGrande L, Ekenga CC,
Farfel MR, Friedman S, Perlman SE, Stellman SD, Walker DJ, Wu D, Yu S, Thorpe LE (2009) Asthma and posttraumatic stress symptoms 5 to 6 years following exposure to the World Trade Center terrorist attack. JAMA 302, 502-16.

10) Reibman J, Lin S, Hwang SA, Gulati M, Bowers JA, Rogers L, Berger KI, Hoerning A, Gomez M, Fitzgerald EF (2005) The World Trade Center residents' respiratory health study: new-onset respiratory symptoms and pulmonary function. Environ Health Perspect 113, 406-11.

11) Banauch GI, Hall C, Weiden M, Cohen HW, Aldrich TK, Christodoulou V, Arcentales N, Kelly KJ, Prezant DJ (2006) Pulmonary function after exposure to the World Trade Center collapse in the New York City Fire Department. Am J Respir Crit Care Med 174, 312-9.

12) Weiden MD, Ferrier N, Nolan A, Rom WN, Comfort A, Gustave J, Zeig-Owens R, Zheng S, Goldring RM, Berger KI, Cosenza K, Lee R, Webber MP, Kelly KJ, Aldrich TK, Prezant DJ (2010) Obstructive airways disease with air trapping among firefighters exposed to World Trade Center dust. Chest 137, 566-74.

13) Izbicki G, Chavko R, Banauch GI, Weiden MD, Berger KI, Aldrich TK, Hall C, Kelly KJ, Prezant DJ (2007) World Trade Center "sarcoid-like" granulomatous pulmonary disease in New York City Fire Department rescue workers. Chest 131, 1414-23.

14) Crowley LE, Herbert R, Moline JM, Wallenstein S, Shukla G, Schechter C, Skloot GS, Udasin I, Luft BJ, Harrison D, Shapiro M, Wong K, Sacks HS, Landrigan PJ, Teirstein AS (2011) "Sarcoid like" granulomatous pulmonary disease in World Trade Center disaster responders. Am J Ind Med (in press)

15) Stellman JM, Smith RP, Katz CL, Sharma V, Charney DS, Herbert R, Moline J, Luft BJ, Markowitz S, Udasin I, Harrison D, Baron S, Landrigan PJ, Levin SM, Southwick S (2008) Enduring mental health morbidity and social function impairment in world trade center rescue, recovery, and cleanup workers: the psychological dimension of an environmental health disaster. Environ Health Perspect 116, 1248-53.

16) Berninger A, Webber MP, Niles JK, Gustave J, Lee R, Cohen HW, Kelly K, Corrigan M, Prezant DJ (2010) Longitudinal study of probable post-traumatic stress disorder in firefighters exposed to the World Trade Center disaster. Am J Ind Med 53, 1177-85.

17) Perrin MA, DiGrande L, Wheeler K, Thorpe L, Farfel M, Brackbill R (2007) Differences in PTSD prevalence and associated risk factors among World Trade Center disaster rescue and recovery workers. Am J Psychiatry 164, 1385-94.

18) Debchoudhury I, Welch AE, Fairclough MA, Cone JE, Brackbill RM, Stellman SD, Farfel MR (2011) Comparison of health outcomes among affiliated and lay disaster volunteers enrolled in the World Trade Center Health Registry. Prev Med (in press) 
19) Antao VC, Pallos LL, Shim YK, Sapp JH 2nd, Brackbill RM, Cone JE, Stellman SD, Farfel MR (2011) Respiratory protective equipment, mask use, and respiratory outcomes among World Trade Center rescue and recovery workers. Am J Ind Med (in press)

20) Zeig-Owens R, Webber MP, Hall CB, Schwartz T, Jaber N, Weakley J, Rohan TE, Cohen HW, Derman O, Aldrich TK, Kelly K, Prezant DJ (2011) Early assessment of cancer outcomes in New York City fire- fighters after the 9/11 attacks: an observational cohort study. Lancet 378, 898-905.

21) Jordan HT, Brackbill RM, Cone JE, Debchoudhury I, Farfel MR, Greene CM, Hadler JL, Kennedy J, Li J, Liff J, Stayner L, Stellman SD (2011) Mortality among survivors of the Sept 11, 2001, World Trade Center disaster: results from the World Trade Center Health Registry cohort. Lancet 378, 879-87.

Michael A. CRANE, MD, MPH

Debra J. MILEK, MD

Yelena GLOBINA, MD, MPH

Leah SEIFU, BS

Philip J. LANDRIGAN, MD, MSc

Department of Preventive Medicine, Mount Sinai School of Medicine, New York, USA 